\title{
Epidemiology and Molecular Characterization of Shiga Toxigenic Escherichia coli from Diarrhoeic Lambs in Andhra Pradesh
}

\author{
T. Sujatha ${ }^{1}$, M. Srivani ${ }^{*}$, K. V. Subramanyam ${ }^{3}$ and T. Srinivasa Rao $^{4}$ \\ ${ }^{I}$ Veterinary Microbiology, Super Specialty Veterinary Hospital SVVU, Vishakapatnam, India \\ ${ }^{2}$ Department of Veterinary Microbiology, ${ }^{4}$ Department of Veterinary Public Health, NTR \\ College of Veterinary Science, Gannavaram, Krishna District, Andhra Pradesh, India \\ ${ }^{3}$ Department of Veterinary Microbiology, College of Veterinary Science, Proddatur, \\ Andhra Pradesh, India \\ *Corresponding author
}

\section{A B S T R A C T}

\begin{tabular}{l} 
K e y w o r d s \\
Epidemiology, \\
Shiga toxigenic \\
$\begin{array}{l}\text { E. coli, Diarrhoeic } \\
\text { lambs }\end{array}$ \\
Article Info \\
\hline $\begin{array}{l}\text { Accepted: } \\
\text { 20 August } 2020 \\
\text { Available Online: } \\
\text { 10 September } 2020\end{array}$ \\
\hline
\end{tabular}

A study was carried to investigate the epidemiology and molecular characterization of Shiga toxigenic Escherichia coli (STEC) from diarrhoeic lambs in Andhra Pradesh. A total of 212 faecal samples from diarrhoeic lambs of 1-7, 8-30, 31-60 and 61-90 days age groups were collected from Vizianagaram, West Godavari, Krishna, districts of Andhra Pradesh. The E. coli isolates were confirmed by cultural, biochemical and molecular methods. The virulence genes of STEC were detected using multiplex PCR. The results of the study revealed that the prevalence rate of $E$. coli in diarrhoeic lambs was $80.18 \%$ of which $87.05 \%$ were identified as STEC. Among the virulence genes of STEC studied, eaeA\&hlyA genes were more prevalent (35.13\%), followed by stxl (12.83\%) and stx 2 $(10.13 \%)$ genes. The combinations of stxl\&eaeA, stx $2 \&$ eaeA genes carrying isolates detected were $5.4 \%$ and $8.1 \%$, respectively. Only four $(2.70 \%)$ STEC isolates carried all the four (stxl, stx2, eaeA and $h l y A$ ) genes. This study indicated that diarrhoeic lambs are the the reservoirs of STEC in this geographic region.

\section{Introduction}

Diarrhoea is one of the important causes of mortality in neonatal lambs causing economic loss to the sheep producers in this geographic area. The most important enteropathogen known to be associated with lamb diarrhoeia is Escherichia coli (E. coli). Shiga-like toxin producing E. coli (STEC) infections have been described in a wide range of domestic and wild animal species, but the natural pathogenic role of STEC has been demonstrated only in weaning pigs, young calves and dogs (Caprioli et al., 2005). Domestic ruminants, especially sheep and cattle, are well known reservoirs of STEC (Blanco et al., 2003 and Caprioli et al., 2005).

The pathogenicity of STEC is mediated mainly through Shiga toxins 1 (which is almost identical to stx produced by Shigella dysenteriae) and 2 encoded by stx 1 and stx 2 
genes, respectively (Paton and Paton 1998). Many STEC also produce intimin, an outer membrane surface adhesion encoded by the chromosomal eaeA gene (Blanco et al., 2004). Intimin is responsible for intimate attachment of STEC to the intestinal epithelial cells, causing attaching and effacing (AE) lesions in the intestinal mucosa (Mora et al., 2005). A factor that may also affect the virulence of STEC strains is the $60-\mathrm{mDa}$ plasmid borne enterohaemolysin (Ehly) which is encoded by the hlyA gene (Schmidt et al., 1995).

Limited studies are available on isolation and characterization STEC from sheep in India (Wani et al., 2003 and Bhat et al., 2007). Therefore, the present research was under taken on epidemiology and molecular characterization of STEC in Andhra Pradesh in order to provide baseline data for taking prophylactic measure in preventing lamb diarrhoeia.

\section{Materials and Methods}

A total of 212 faecal samples from diarrhoeic lambs of 1 to 90 days age group were collected at random from organized sheep farms and individual flocks of Vizianagaram, West Godavari, and Krishna Districts of Andhra Pradesh (AP) during the period from October 2017 to June 2018. Age and sex of diarrhoeic lambs were recorded during sampling. The faecal samples were collected from rectum using sterile cotton swabs. After collection, the swabs were immediately transported to the Department of Veterinary Microbiology, NTR College of Veterinary Science, Gannavaram in ice-cooled containers for $E$. coli isolation.

\section{Isolation and identification of $E$. coli}

The rectal swabs were streaked on MacConkey (Hi Media) agar plates and incubated overnight at $37^{\circ} \mathrm{C}$ for $24 \mathrm{~h}$. The plates with pink colonies were selected and inoculated on Eosin methylene blue (EMB) agar plate and re-incubated at $37^{\circ} \mathrm{C}$ for $24 \mathrm{~h}$. Typical greenish metallic sheen colonies on EMB were tested for Gram's staining and motility.

The organisms which were Gram negative were further tested for motility. The organisms which were Gram negative and motile were subsequently grown on nutrient agar (NA) slants in duplicate and stored at $4^{\circ}$ $\mathrm{C}$ for further biochemical tests (Hitchins et al., 1992) and (Cruikshank et al.,1975) and molecular characterization.

\section{Molecular Characterization of $E$. coli}

The biochemical results were confirmed by PCR amplification using E. coli 16s rRNA specific primers quoted by Sun Dong-bo et al., (2011) (E16S-F: ATCAACCGAGATTCCCCCAGT E16S-R: TCACTATCGGTCAGTCAGGAG) with $231 \mathrm{bp}$ amplified product.

\section{PCR conditions for detection E.coli I6SrRNA}

PCR reactions were carried out in an Eppendorf thermal cycler. The amplification conditions were $5 \mathrm{~min}$ of denaturation at $95^{\circ} \mathrm{C}$, followed by 35 cycles of $95^{\circ} \mathrm{C}$ for 1 min, $50^{\circ} \mathrm{C}$ for $50 \mathrm{~s}$, and $72^{\circ} \mathrm{C}$ for $1 \mathrm{~min}$, and a final extension step of $72^{\circ} \mathrm{C}$ for $10 \mathrm{~min}$. DNA amplified by PCR was subjected to $2 \%$ agarose gel electrophoresis as described by sambrook and Russel (2001).

\section{Multiplex PCR for detection of virulence genes}

The primers used in the present study for the detection of virulence genes (stx1, stx2, eaeA, hlyA) of STEC were as described by Paton and Paton (1998). 
Standardization of multiplex PCR protocol for detection of stxl, stx2, eaeA \& hlyA virulence gene

Polymerase chain reaction for amplification of the stxl, stx2, eaeA, hlyA genes was set up in $25 \mu \mathrm{L}$ reaction. Following initial trails with varying concentration of components, the reaction mixture was optimized as below.

PCR tube containing the reaction mixture was flash spun in a microcentrifuge to settle the reactants at the bottom. Polymerase chain reaction assay was performed in Eppendorf thermal cycler with heated lid. Samples were subjected to 35 cycles as per the procedure (Paton and Paton, 1998).

\section{Results and Discussion}

The faecal samples (212) were screened for $E$. coli by cultural and biochemical methods followed by confirmation of E. coli by molecular methods with PCR revealed that 170 out of 212 samples were positive for $E$. coli, giving an overall prevalence rate of $80.18 \%$. Consistent with present findings, Aklilu et al., (2013) reported 84\% prevalence rate in diarrhoeic lambs and Srivani et al., (2017) reported $80.53 \%$ ) in diarrhoeic buffalo calves in India (AP) and Ethiopia, respectively. Contrary, lower prevalence rate of $E$. coli was reported in diarrhoeic lambs by Nasr et al., (2014) in Egypt (34.20\%) and Wani et al., (2008) in Kashmir valley, India $(22.18 \%)$.This study observed higher prevalence of $E$. coli in West Godavari district (86.41\%), while lower $(72.83 \%)$ prevalence was found in Krishna district. The differences in the prevalence rates of $E$. coli may be due to differences in feeding and management practices among the districts studied.

Table.1 Details of the primers used for the detection of stxl, stx2, eaeA and hlyA genes

\begin{tabular}{|c|c|c|c|c|}
\hline Primer & $\begin{array}{l}\text { Target } \\
\text { gene }\end{array}$ & Primer sequence & $\begin{array}{c}\text { Amplicon } \\
\text { size(bp) }\end{array}$ & Reference \\
\hline Stx1F & \multirow[t]{2}{*}{ stxl } & ATAAATCGCCATTCGTTGACTAC & \multirow[t]{2}{*}{180} & \multirow{8}{*}{$\begin{array}{l}\text { Paton and } \\
\text { Paton. } \\
\text { (1998) }\end{array}$} \\
\hline Stx1R & & AGAACGCCCACTGAGATCATC & & \\
\hline Stx2 F & \multirow[t]{2}{*}{ stx 2} & GGCACTGTCTGAAACTGCTCC & \multirow[t]{2}{*}{255} & \\
\hline Stx2 R & & TCGCCAGTTATCTGACATTCTG & & \\
\hline eaeAF & \multirow[t]{2}{*}{ eaeA } & GACCCGGCACAAGCATAAGC & \multirow[t]{2}{*}{384} & \\
\hline eaeAR & & CCACCTGCAGCAACAAGAGG & & \\
\hline hlyAF & \multirow[t]{2}{*}{ hlyA } & GCATCATCAAGCGTACGTTCC & \multirow[t]{2}{*}{534} & \\
\hline hlyAR & & AATGAGCCAAGCTGGTTAAGCT & & \\
\hline
\end{tabular}

Table.2 Optimized PCR mixture for amplification of STEC virulence genes

\begin{tabular}{|c|c|}
\hline Components & Quantity $(\mu \mathrm{L})$ \\
\hline Master mix & $12.5 \mu \mathrm{L}$ \\
\hline Primer F $-(20$ pmol $)$ & $0.12 \mu \mathrm{L}$ X4 \\
\hline Primer R- $(20$ pmol) & $0.12 \mu \mathrm{L} \mathrm{X4}$ \\
\hline Template & $5.00 \mu \mathrm{L}$ \\
\hline NFW water & $6.54 \mu \mathrm{L}$ \\
\hline Total & $25 \mu \mathrm{L}$ \\
\hline
\end{tabular}


Table.3 Distribution of virulence genes in E. coli isolates from diarrhoeic lambs

\begin{tabular}{|c|c|c|}
\hline $\begin{array}{l}\text { Virulen } \\
\text { ce Gene }\end{array}$ & $\begin{array}{l}\text { No.of } E \text {. coli isolates from } \\
\text { diarrhoeic calves with the virulence } \\
\text { gene }(\mathrm{N}=148)\end{array}$ & $\%$ \\
\hline Stx 1 & $\begin{array}{l}1 \\
9\end{array}$ & 12.83 \\
\hline Stx 2 & $\begin{array}{l}1 \\
5\end{array}$ & 10.13 \\
\hline hlyA & $\begin{array}{l}1 \\
7\end{array}$ & 11.48 \\
\hline Stx1,eaeA & 8 & 5.40 \\
\hline Stx1,hlyA & 7 & 4.72 \\
\hline Stx 2 ,eaeA & $\begin{array}{l}1 \\
2\end{array}$ & 8.10 \\
\hline Stx $2, h l y A$ & 7 & 4.72 \\
\hline eaeA, hlyA & $\begin{array}{l}5 \\
2\end{array}$ & 35.13 \\
\hline Stx 1,stx 2,hlyA & 7 & 4.72 \\
\hline $\begin{array}{c}\text { Stx1,stx2,eaeA,hl } \\
y A,\end{array}$ & 4 & 2.70 \\
\hline
\end{tabular}

Fig.1 PCR assay targeting virulence genes of STEC

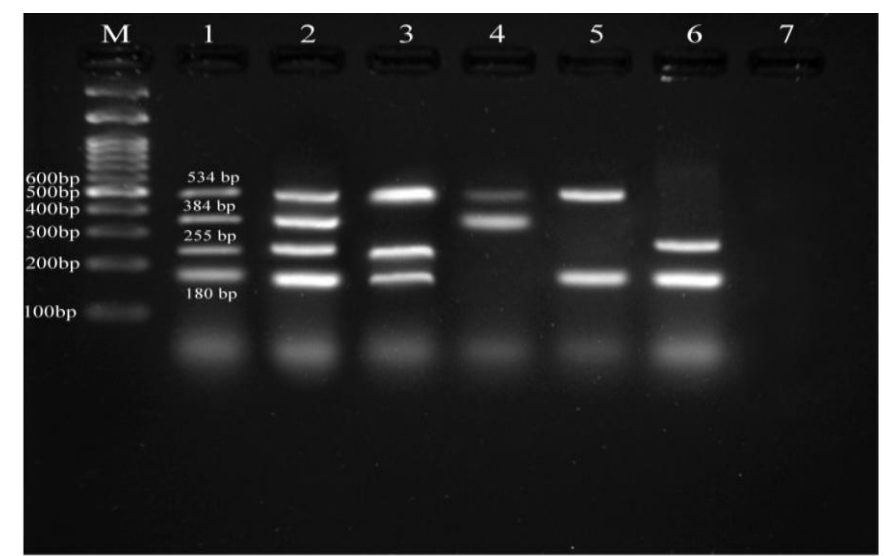

Lane $\mathrm{M}$ : DNA ladder of $100 \mathrm{bp}$

Lane :1 slandered E.coli positive control carrying Stxl, Stx2,eaeA and hlyA genes Lane 2 to 6 : Isolates carrying shigatoxin genes

Lane 7: Negative control

The prevalence of E. coli associated diarrhoea was high in younger lambs compared to older lambs. Higher prevalence $(84 \%)$ was detected in one to seven day old lambs, followed by $80.80 \%$ in $8-30$ days, $80.32 \%$ in 31 to 60 days, while $72.72 \%$ was observed in $61-90$ day old lambs. Parallel to this findings of Srivani et al., (2017) and Abdulgayeid et al., (2015) reported a higher prevalence of $E$. coli in 1-7 day old calves compared to older calves. Higher prevalence of E. coli associated diarrhoea in young lambs may be 
due to ill developed rumen and poor immune status in those lambs that deprived of colostrum or delay in colostrum feeding compared to older lambs. Matte et al., (1982) found that $61 \%$ of colostral immunoglobulin containing $80 \mathrm{~g} / \mathrm{ml}$ of $\mathrm{IgG}$ absorbed in six hours and decreases sharply, thereafter. This indicates that the first six hours are the period in which maximum absorption of colostral immunoglobulins takes place.

Out of 170 isolates from diarrhoeic lambs, $148(87.05 \%)$ were identified as STEC. The prevalence of STEC detected in the present study was higher compared to the prevalence of STEC reported by Kiranmayi et al., (2011) $(54.80 \%)$ and lower compared to the results reported by Ferreira et al., (2015) (78.3\%) in sheep.

Multiple virulence genes are associated with the pathogenicity of STEC. Among the virulence genes of STEC studied, eaeA\&hlyA were more prevalent $(35.13 \%)$ in diarrhoeic lambs. Similar results of higher frequencies of eaeA\&hlyA genes than stxland stx2 genes were reported by Wani et al., (2003) in diarrhoeic calves in Kashmir valley, India. The present findings are also parallel to the results reported by Badouei et al., (2010) who detected higher prevalence of eaeA\&hlyA genes in healthy and diarrhoeic calves in Iran. Similar results of higher prevalence of eaeA\&hlyA genes in STEC isolates from diarrhoeic calves were also reported in other studies (Blanco et al., 2004 and Aidar et al., (2007). Several investigators have observed strong association between the carriage of $e a e A$ gene and the capacity of STEC to cause severe human disease (Blanco et al., 2004 and Beutin et al., 2004).

This study also detected a high percentage $(12.83 \%)$ stxlgene compared to stx2gene $(10.13 \%)$ in diarrhoeic lambs. The present results are comparable with Srivani et al.,
(2017) who reported highest stxlgene (16.04) compared to stx2 gene (12.64\%) in diarrhoeic calves. Contrary to the present findings, Wani et al., (2003) reported more prevalence of stx2 than stxlgene in diarrhoeic calves and lambs in Kashmir valley, India.

The combinations of stx 1 \&eaeA, stx 2 \&eaeA genes carrying isolates detected were $5.4 \%$ and $8.1 \%$, respectively. Similar to our findings Rigobelo et al., (2006) detected the association of eae gene with the stx 2 gene in STEC isolates from diarrhoeic calves in Brazil. However, Wani et al., (2004) observed uniform association of eae gene with stxl and stx2 in diarrhoeic calves in Kashmir valley, India.

In this study, only four (2.70\%) STEC isolates carried all the four (stxl, stx2, eaeA and $h l y A$ ) genes. However, Maldonado et al., (2005) reported that $84 \%$ of the food and clinical isolates from outbreaks carried all four virulence genes. This discrepancy may be due to the fact that the samples were not from outbreaks, implying more diversity amongst isolates and therefore, less prevalence of the target virulence genes combination. On the other hand, the isolates reported by Maldonado et al., (2005) were of outbreak origin, were perhaps more homogenous in their genetic makeup, resulting in higher carriage rate of virulence genes. The presence of virulent strains of Escherichia coli in the environment may be a potential source of contamination of food and the water supply. Moreover, these strains may comprise a potential reservoir of virulence genes acquired from different sources (e.g., bacteriophages and plasmids). E. coli is a very dynamic organism with capacity for horizontal gene transfer to increase genetic diversity and under certain circumstances this can lead to the emergence of new pathogenic strains (Donnenberg and Whittam, 2001). 
The present study concluded that higher prevalence of STEC in diarrhoeic lambs may indicate that diarrhoeic lambs are the potential reservoirs of STEC in this geographic region which may have public health significance.

\section{Acknowledgements}

The authors are thankful to the Sri Venkateswara Veterinary University, Tirupati, for providing necessary funds and facilities to carry out the present PG research work.

\section{References}

Abdulgayeid, M., Hazem Shahin., Seham Foad., and Madiha, S., Ibrahim. (2015). Molecular characterization of Escherichia coli isolated from buffalo calves in El-Behera Governorate. Alexandria Journal of Veterinary Sciences, 47 (1): 90-96.

Aidar, U L., Blanco, J., Blanco, M., Blanco, J. E., Leomil, L., Dahbi, G., Mora, A., Onuma, D L., Silveira, W. D., and Pestana de Castro, A, F. (2007). Serotypes, virulence genes, and intimin types of Shiga toxin-producing Escherichia coli (STEC) and enteropathogenicE. coli (EPEC) isolated from calves in Sao Paulo, Brazil. International Journal of Food Microbiology, 115(3):297-306.

Aklilu, M., Sisay, T., Tefera, G., and Tekalign, B. (2013). Identification and biotyping of Escherichia coli from diarrheic lambs in and around Debre Birhan town, Ethiopia. Journal of Environmental and Analytical Toxicology, 3: 6.

Badouei, M, A., Salehi, T. Z., Khorasgani, M. R., Tadjbakhsh, H., Brujeni, G. N., and Nadalian, M. G. (2010). Virulence gene profiles and intimin subtypes of Shiga toxin-producing Escherichia coli isolated from healthy and diarrhoeic calves. Veterinary Record, 167(22):858861.

Beutin, L., Geier, D., Steinruck, H., Zimmermann, S., and Scheutz, F. (1993). Prevalence and Some Properties of Verotoxin (Shiga-Like Toxin)Producing Escherichia coli in Seven different species of healthy domestic animals. Journal of Clinical Microbiology, 31 (9): 2483-2488.

Bhat, M. A., Nishikawa, Y., and wani, S, A. (2007). Prevalence and virulence gene profiles of shiga toxin-producing Escherichia coli and enteropathogenic Escherichia coli from diarrhoeic and healthy lambs in India. The Official Journal of the International Goat Association, 75(1): 65-75.

Blanco, M., Blanco, J. E., Mora, A., Dahbi, G., Alonso, M. P., Gonzalez, E. A., Bernardez, M. I., Blanco, J. (2004). Serotypes, virulence genes, and intimin types of Shiga toxin (verotoxin)producing Escherichia coli isolates from cattle in Spain and identification of a new intimin variant gene (eae-xi). Journal of Clinical Microbiology, 42:645-650.

Blanco, M., Blanco, J. E., Mora, A., Rey, J., Alonso, J. M., Hermoso, M., Hermoso, J., Alonso, M. P., Dahbi, G., Gonzalez, E. A., Bernardez, M. I., and Blanco, J. (2003). Serotypes, virulence genes, and intimin types of shiga toxin (Verotoxin)producing Escherichia coli isolates from healthy sheep in Spain. Journal of Clinical Microbiology, 41(4): 13511356.

Caprioli, A., Morabito, S., Brugere, H. and Oswald, E. (2005). Enterohaemorrhagic Escherichia coli: emerging issues on virulence and modes of transmission. Veterinary Research., 36:289-311.

Cruickshank, R., Duguid, J. P., Marmion, B. P. and Swain, R. H. A. (1975). Medical 
Microbiology, (12 $2^{\text {th }}$ edition)

Dong-bo, S U N., Rui, W. U., Xian-jing, H. E., Shuang Wang., Yun-cheng Lin., Xu, H. A. N., Yue- qiang Wang., Ting-ting, G. U. O., Guo-jun, W. U. and Ke-li, Yang. (2011) Development of a Multiplex PCR for Diagnosis of Staphylococcus aureus, Escherichia coli and Bacillus cereus from Cows with Endometritis. Agricultural Sciences in China., 10(10): 1624-1629.

Donnenberg, M. S. and Whittam, T. S. (2001). Pathogenesis and evolution of virulence in enteropathogenic and enterohaemorrhagic Escherichia coli. Journal of Clinical Investigation., 39: 270-74.

Feria, C. E., Ferreira, J. D., Correira, J., Goncalves., and Canica. M. (2002). Patterns and mechanisms of resistance to beta-lactams and beta-lactamase inhibitors in uropathogenic Escherichia coli isolated from dogs in Portugal. Journal of Antimicrobial Chemotherapy, 49:77-85.

Hitchins, A. D., Hartman, P. A., Todd, E. C. D. (1992) Coliform Escherichia coli and its toxins. In: Vanderzant, C., Splittstoesser, D. (Eds), Compendium of Methods for the Microbiological Examination of Foods, pp. 327-329.

Kiranmayi, C. B., Krishnaiah, N., and Mallika, E. N. (2011) Escherichia coli O157:H7 - An emerging pathogen in foods of animal origin. Veterinary World, 3: 382- 389.

Maldanado, Y., Fiser, J. C., Nakatsu, C. H., and Bhunia, A. K. (2005). Cytotoxicity potential and genotypic characterization of Escherichia coli isolates from environmental and food sources. Applied and Environmental Microbiology, 71: 1890-98

Matte, J. J., Girard, C. L., Seoane, J. R., Brisson, G. J. (1982) Absorption of colostral immunoglobulin $G$ in the newborn dairy calf. Journal of Dairy Science 65: 1765-1770

Mora, A. (2007) Phage types, virulence genes and PFGE profiles of shiga toxinproducing $E$. coli $\mathrm{O} 157: \mathrm{H} 7$ isolated from raw beef, soft cheese and vegetables in Lina (Peru). International Journal of Food Microbiology, 114: 204-210

Nasr, M., Bakeer, N. M., Hammouda, H. A., and Omar, A. A. (2014) Epidemiological, clinical and bacteriological studies on bacterial lamb enteritis at Behera Province, Egypt. Alexandria Journal of Veterinary Sciences, (43): 8-16.

Paton, A. W. and Paton, J. C. (1998) Detection and Characterization of Shiga Toxigenic Escherichia coli by Using Multiplex PCR Assays for stx 1, stx 2, eaeA, Enterohemorrhagic E. coli hlyA, $\mathrm{rfb}$ O111, and rfb O157. Journal of Clinical Microbiology, 36(2), 598-602.

Rigobelo, E.C, Gamez, H.J., Marin, J.M., Macedo, C., Ambrosin, J.A., and Ávila F.A, (2006). Virulence factors of Escherichia coli isolated from diarrheic calves. Arquivo Veterinary Research and Animal Science, 37(2): 1-7.

Sambrook, J., and Russell, D. W. (2001) Molecular cloning - a laboratory manual, $3^{\text {rd }}$ edition, Cold Spring Harbor Laboratory Press, Cold Spring Harbor.

Schmidt, H., Beutin, L., and Karch, H. (1995). Molecular analysis of the plasmid-encoded hemolysin of Escherichia coli O157:H7 strain EDL 933. Infection and Immunity, 63(3): 1055-1061.

Srivani, M., Reddy, Y. N., Subramanyam, K. V., Reddy, M. R., and Rao, T. S. (2017) Prevalence and antimicrobial resistance pattern of Shiga toxigenic Escherichia coli in diarrheic buffalo calves. Veterinary world, 10(7): 774.

Wani, S, A., Hussain, I, Fayaz, I., Mir, M. A., and Nishikawa, Y. (2008). Subtype 
analysis of stx 1 , stx 2 and eae genes in shiga toxin-producing Escherichia coli (STEC) and typical and atypical enteropathogenic E. coli (EPEC) from lambs in India. The Veterinary Journal, 182: 489-490.

Wani, S, A., Pandit, F, I., Samanta, I., Bhat, M. A., Buchh, A. S. (2004) Molecular epidemiology of of shiga toxin producing Escherichia coli (STEC) in
India. Current science, 87(10): 1346135

Wani, S. A., Bhat, M. A, Munshi, Z. H., Qureshi, S., and Buch, A. S. (2003) Isolation and in- vitro sensitivity pattern of pathogenic Escherichia coli from diarrhoeic lambs and calves. Journal of Animal Sciences, 73 (2): 168-170.

\section{How to cite this article:}

Sujatha, T., M. Srivani, K. V. Subramanyam and Srinivasa Rao, T. 2020. Epidemiology and Molecular Characterization of Shiga Toxigenic Escherichia coli from Diarrhoeic Lambs in Andhra Pradesh. Int.J.Curr.Microbiol.App.Sci. 9(09): 3070-3077.

doi: https://doi.org/10.20546/ijcmas.2020.909.379 